\title{
PENGARUH INTENSITAS PENDIDIKAN AGAMA ISLAM DI LINGKUNGAN KELUARGA DENGAN EQ PESERTA DIDIK
}

\author{
Betti Megawati ${ }^{1}$, Fauzi Ahmad Syawaluddin ${ }^{2}$, Syahputra Siregar ${ }^{3}$ \\ 1,2,3 Universitas Al Washliyah Labuhanbatu \\ Email kontributor: bettimegawati0@gmail.com
}

\begin{abstract}
Abstrak
Penelitian bertujuan melihat pengaruh intensitas PAI dalam keluarga dengan Emotional Quotient (EQ) siswa. Penelitian di MTs Negeri 2 Rantauprapat. Penelitian menggunakan metode survei. Menggunakan analisis regresi dalam mengukur pengaruh perubahan variabel yang ada. Jumlah sampel dalam penelitian 140 siswa. Hasil penelitian terdapat hubungan positif antara intensitas PAI di lingkungan keluarga dengan kecerdasan emosional (EQ) siswa. Dilihat dari nilai koefisien korelasi bahwa $r_{x y}=0,427>r_{t}(0,05)=$ 0,312 , taraf signifikan $r_{x y}=0,427>r_{t}(0,01)=0,403$ berarti signifikan. Terdapat hubungan positif antara intensitas PAI di lingkungan keluarga dengan Kecerdasan Emosional (EQ), melalui uji $F_{\text {reg }}$ diperoleh 8,495, kemudian dikonsultasikan dengan tabel $F_{t}(0,05)=4,10$ dan $F_{t}(0,01)=7,35$. Sehingga $F_{r e g}=8,495>F_{t}(0,05)=4,10$ maka $F_{t}(0,01)=7,35$ sehingga hipotesis apakah terdapat hubungan positif antara intensitas PAI di lingkungan keluarga dengan kecerdasan emosional (EQ) siswa dapat diterima.
\end{abstract}

Kata kunci: Intensitas PAI, Kecerdasan Emosional (EQ), MTs Negeri 2 Rantauprapat

\begin{abstract}
This study aims to see the effect of PAI intensity in the family with the Emotional Quotient (EQ) of students. The research took place at MTs Negeri 2 Rantauprapat. The research used a survey method. Using regression analysis in measuring the effect of changing existing variables. The number of samples was 140 students. There is a positive relationship between PAI intensity in the family environment and the Emotional Quotient (EQ). It can be seen from the correlation coefficient value, it is known that $r_{x y}=0.427>r_{t}(0.05)=0.312$ then the significant level of $r_{x y}=0.427>r_{t}(0.01)=0.403$ means significant. There is a positive relationship between the intensity of PAI in the family environment with the Emotional Quotient (EQ) of students, through the $\mathrm{F}_{\text {reg }}$ test, the value is 8.495 , then the results are consulted with the table $F_{t}(0.05)=4.10$ and $F_{t}(0.01)=7.35$. So that $F_{\text {reg }}=8.495>F_{t}(0.05)$ $=4.10$ then $F_{t}(0.01)=7.35$ so that the hypothesis that there is a positive relationship between the intensity of PAI in the family environment with the Emotional Quotient (EQ) Charter is acceptable.
\end{abstract}

Keywords: PAI intensity, Emotional Quotient (EQ), MTs Negeri 2 Rantauprapat 


\section{A. PENDAhuluan}

Pendidikan merupakan tahapan manusia untuk mendapatkan ilmu pengetahuan (Ramen A Purba et al., 2020). Pelaksanaan pendidikan tidak akan pernah berhenti, karena sejalan dengan perkembangan teknologi yang dinamis. Pendidikan akan terus berjalan karena kebutuhan industri dan dunia kerja yang sangat kompleks. Pendidikan akan semakin berkembang seiring dengan perkembangan industri yang terus mengalami evolusi. Pendidikan terus berputar seturut dengan perkembangan ilmu pengetahuan. Pendidikan adalah segala usaha yang dilakukan untuk mendidik manusia agar tumbuh dan berkembang dengan memiliki potensi atau kemampuan sebagaimana mestinya. Pendidikan telah menjadi kesadaran semua pihak, dimana pendidikan diyakini sebagai elemen paling substansial bagi proses transformasi dalam skala luas, mulai transformasi pengetahuan, transformasi nilai, hingga transformasi sosial kemasyarakatan. Terdapat tiga lingkungan yang bertanggung jawab mendidik anak, yakni keluarga, sekolah dan masyarakat. Ketiga lingkungan tersebut tidak dapat dipisahkan. Akan tetapi dari ketiganya, lingkungan keluarga memiliki tanggung jawab utama dan pertama dalam bidang pendidikan (Sudarmanto et al., 2021).

Tantangan dunia pendidikan saat sekarang yakni rendahnya Emotional Quotient (EQ). Emotional Quotient (EQ) yakni kesanggupan manusia dalam mengakui, menghargai, mengendalikan, dan mengatur hati serta perasaan secara individu maupun individu lain di dalam atau di luar lingkungannya. Hati serta perasaan yang dimaksud erat kaitannya dengan emosional yang mengarah kepada pandangan akan penjelasan terhadap sebuah atau suatu ikatan (Rosyida, 2020). Tingginya tingkat kriminal di kalangan peserta didik seperti tawuran, begal, penggunaan narkoba, jambret, hingga seks bebas merupakan bukti rendahnya Emotional Quotient (EQ) dikalangan pelajar. Untuk memperlihatkan eksistensinya agar dikatakan jantan, peserta didik dengan gampangnya merokok. Tanpa memikirkan kesehatan tubuhnya. Agar dikatakan bergaul dan berani, peserta didik dengan mudah ikut-ikutan tawuran dengan peserta didik dari sekolah lain hanya karena permasalahan sepele (Syahrum et al., 2019). Agar diterima bergabung dengan kelompok tertentu, peserta didik melakukan begal yang membahayakan nyawa orang lain hanya untuk memenuhi persyaratan. Rendahnya Emotional Quotient (EQ) yang berhubungan dengan perilaku kriminal menyebabkan banyak peserta didik putus sekolah atau tidak mampu menyelesaikan pendidikannya hingga lulus (tamat). Situasi yang miris dan memprihatinkan (Herwati, 2016).

Pendidikan Agama Islam berfungsi guna memperadabkan serta menuntun manusia sehingga sanggup untuk melaksanakan/mengemban amanat/tugas yang merupakan sabda Allah. Adapun amanat/tugas yang diharus dilaksanakan/diemban oleh manusia yaitu melaksanakan kewajiban hidup sebagai manusia selama masih diberikan nafas kehidupan oleh Allah (Hanafie Das et al., 2020). Seperti Abdullah yang patuh serta setia kepada seluruh ketentuan/kaidah yang menjadi kemauan Allah. Maupun seperti khalifahNya Allah di dunia, dengan kewajiban melaksanakan kekhalifahan kepada individu, bersama keluarga, dan ditengah-tengah lingkungan masyarakat maupun kewajiban melakukan kekhalifahan kepada isi alam yang merupakan ciptaan Allah. Sungguh mulia hakikat Pendidikan Agama Islam. Jika dilaksanakan secara sungguhsungguh, niscaya keberkatan dan anugrah yang berasal dari Allah akan senantiasa diterima dan diturunkan (Boiliu, 2018). 
Pendidikan agama sangat penting guna merubah sikap peserta didik menjadi lebih baik. Keberhasilan suatu pendidikan dapat diukur tidak hanya dari hasil belajar, tetapi juga dari cara peserta didik tersebut bersikap, yang merupakan cerminan dari kecerdasan emosionalnya. Menurut Dimyati dan Mudjiono dalam (Ramen Antonov Purba, 2018), bahwa hasil belajar merupakan suatu proses untuk melihat sejauh mana siswa dapat menguasai pembelajaran setelah mengikuti kegiatan proses belajar mengajar, atau keberhasilan yang dicapai seorang peserta didik setelah mengikuti kegiatan pembelajaran yang ditandai dengan bentuk angka, huruf, atau simbol tertentu. Tetapi tak cukup hanya itu, peserta didik juga wajib memiliki kecerdasan emosional yang baik, karena hal tersebut merupakan cerminan sikap seorang peserta didik yang baik dan bijaksana. Faktor dari luar peserta didik berupa lingkungan keluarga terutama tanggung jawab orang tua sangat mempengaruhi serta menentukan keberhasilan belajar. Setiap orang tua menginginkan anaknya pandai dan saleh. Selain itu juga memiliki kecerdasan emosional yang baik. Harapan tersebut akan terwujud apabila orang tua mendukung pendidikan anak dengan tidak menyerahkan sepenuhnya pendidikan anak hanya kepada pihak sekolah. Lalu melupakan perannya untuk senantiasa memperhatikan dan memberikan kasih sayang kepada anak (Ramen A Purba et al., 2021). Bekerja keras dan banting tulang secara maksimal guna memberikah nafkah halal dan baik merupakan tanggung jawab keluarga dalam hal ini orang tua, namun bagaimanapun sibuknya, keluarga dalam hal ini orang tua, berkewajiban guna fokus memberikan perhatian. Pendidikan anaknya jangan sampai terbengkalai atau terlupakan. Pada ajaran agama Islam, orang tua kepala dan pemimpin dalam keluarga serta berkewajiban untuk memelihara keluarganya dari api neraka. Allah swt berfirman pada Q.S. at-Tahrim ayat 6:

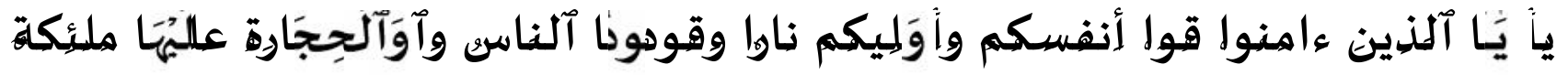

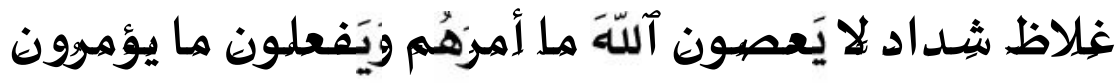

Artinya: "Hai orang-orang yang beriman, peliharalah dirimu dan keluargamu dari api neraka yang bahan bakarnya adalah manusia dan batu ; penjaganya malaikat-malaikat yang kasar, keras, dan tidak mendurhakai Allah terhadap apa yang diperintahkan-Nya kepada mereka dan selalu mengerjakan apa yang diperintahkan ( Q.S. at-Tahrim/66:6)”.

Ayat tersebut memerintahkan kepada kepada keluarga khususnya orang tua guna bertanggung jawab atas anggota keluarga nya dengan selalu mengerjakan apa yang diperintahkan-Nya dan menghindari setiap hal agar terjauh dari api neraka. Oleh karena itu, keluarga khususnya orang tua memiliki tanggungjawab kewajiban guna mengenalkan serta memotivasi dan mendukung anak-anaknya dalam kehidupan keagamaan. Keluarga dalam hal ini orang tua wajib mengajar anak-anaknya secara baik dalam bidang akidah, sesuai dengan sebagai bekal dan modal pengetahuan agama dan kebudayaan Islam. Islam memandang jika keluarga dalam hal ini orang tua adalah sosok teladan yang dapat menjadi contoh guna memperoleh pengajaran moralitas begitupula dengan informasi terkait keagamaan. Keluarga dalam hal ini orang tua, khususnya ayah begitupula ibu dari anak-anaknya, sejatinya memperlihatkan nilai-nilai bernuansa positif ketika bertindak dan berkelakuan sehari-hari, baik 
dari segi ucapan atau perbuatannya, karena seluruh apa saja yang dilakukan oleh orang tua nya akan berpengaruh pada kecerdasan emosional dari anak-anaknya.

Pendidikan Agama Islam sangat fokus kepada pemberian contoh nyata dalam kehidupan, membiasakan hidup baik, memberikan curahan perhatian serta masukan atau saran yang dapat dilakukan melalui percakapan, bincang santai, atau diskusi tatap muka, namun konsisten menerapkan ketepatan waktu serta kerapian dengan mengacu kepada aturan-aturan yang ada. Seluruh apa saja yang dikerjakan akan dicontoh serta memiliki pengaruh terhadap anak-anaknya. Sangat tidak layak ketika mereka yang memberikan nasihat kepada anak-anaknya agar senantiasa berakhlak serta bertindah, bertingkah secara mulia, sebaliknya justru bertindak negatif melumuri dirinya dengan akhlak dan tindakana yang tidak terpuji atau tercela, tak ada jalan atau solusi lain untuk menanamkan dan menekankan akhlak yang mulia kepada anak-anak selain mempraktikkannya dalam kehidupan sehari-sehari. Tentunya dengan konsisten serta penuh dengan tanggung jawab. Anak-anak mempunyai peranan yang sangat sentral serta sangat penting sebagai generasi penerus bagi kedua orang tuanya serta generasi penerus bagi nusa, bangsa, serta negara. Lahirnya anak-anak ditengah-tengah keluarga, merupakan kekayaan keluarga khususnya orang tua dan perhiasan yang berharga bagi nusa, bangsa, serta negara. Hal ini seperti yang terungkap dalam firman Allah swt. QS. al-Kahfi ayat 46:

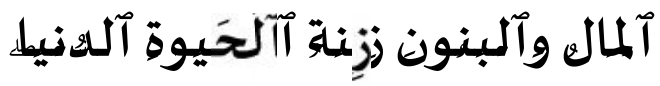

Artinya: "Harta dan anak adalah perhiasan dunia"(QS. al-Kahfi/18:46).

Menjalankan dan melaksanakan tanggungjawab melalui pendidikan dengan menempatkan anak-anaknya di sekolah yang berbasis Islam belum cukup menjadi solusi sebagai proses untuk membentuk serta membangun kecerdasan emosional dalam diri anak. Banyak keluuarga khususnya orang tua yang terkesan melepaskan seluruh tanggung jawabnya kepada guru ketika anaknya telah masuk ke sekolah. Segala hak dan kewajiban sebagai pendidik dianggap telah berpindah kepada guru di sekolah. Padahal pendidikan yang berkualitas adalah pendidikan yang terjadi karena hubungan kemitraan yang sinergis antara keluarga, sekolah, dan masyarakat. Peran atau tanggung jawab keluarga khususnya orang tua bukan hanya sebatas menyekolahkan atau membiayai persekolahan serta pendidikan anak-anaknya, memenuhi serta memfasilitasisarana dan prasarana yang menunjang, namun keluarga khususnya orang tua memiliki tanggungjawab serta berkewajiban dalam memberikan dukungan untuk kelancaran pendidikan anak-anaknya. Keluarga khususnya orang tua menjalankan langkah untuk mendidik anak-anaknya melalui tindakan pengawasan serta monitoring, sehingga anak-anaknya mengerti batasan dan lingkup dalam bertindak serta bertingkah laku, mana yang harus dilakukan serta yang tidak boleh dikerjakan serta dilakukan. Pengawasan dan monitoring tersebut tidak dapat mengurangi kebebasan anak apalagi sampai terkesan mengekangnya, sehingga keluarga khususnya orang tua harus bijaksana serta pintar dalam menghadapi anak-anaknya di setiap keadaan serta kondisi, maupun situasi. Anak-anak silahkan diberikan batasan-batasan tanpa harus mengekang atau menghalangi, atau terkesan melarang keinginan serta aspirasi mereka dalam bergerak atau bertindak. 
Seperti yang telah dikatakan sebelumnya perihal tantangan dunia pendidikan yang berkaitan erat dengan masa depan peserta didik (Ramen Antonov Purba, 2021). Seperti fitrah yang merupakan kemampuan perangai/pembawaan dari manusia. Hal ini sejatinya menjadikan manusia sadar akan kelemahan/ketidakmandirian yang ada pada dirinya untuk kemudian tidak melakukan sesuatu diluar kemampuan kemanusiannya. Manusia jangan sampai merasa dirinya seperti Allah Pencipta Alam Semesta yang kekuatannya tidak memiliki batasan (Batubara, 2021). Berdasarkan penjelasan ini dapat ditarik korelasi bahwa Pendidikan Agama Islam memiliki tugas dalam hal membangun serta membawa peserta didik dalam hal ini manusia supaya sadar dengan kondisi dan keberadaannya yang memiliki batasan. Kemudian meningkatkan dan menumbuhkan keyakinan keimanan dan ketakwaan terhadap Tuhan Yang Maha Esa empunya Alam Semesta yang kuasa dan kekuatannya tidak ada batasnya. Selain itu, Pendidikan Agama Islam pun memiliki tanggungjawab guna membangun dan membawa peserta didik dalam hal ini manusia sehingga sanggup untuk melakukan pengendalian dirinya serta meminimalkan/menghapuskan unsur-unsur tidak baik di mana sebelumnya menguasai dirinya supaya jangan malah menguasai hidupnya sebagai makluk hidup (Saputra, 2019). Tetapi hendaknya unsur yang baik dan sesuai dengan perintah Allah SWT dikembangkan dan terpancar melalui kepribadian yang dijalaninya dalam hidupnya. Salah satunya yakni sikap pengendalian diri yang memiliki kaitan erat dalam konteks emosi. Selain yang telah dikatakan sebelumnya, Pendidikan Agama Islam memiliki filosofi bahwa ketika seorang peserta didik mendapatkan kesuksesan dan berhasil, situasi dan raihan tersebut bukan semata-mata berasal dari kepintaran pikirannya saja, tetapi turut pula karena hadirnya peranan lain yakni Emotional Quotient (EQ) atau yang sering dikatakan kecerdasan emosional. Sehingga dalam Pendidikan Agama Islam ada yang dinamakan karakter, sifat, sikap, dan karakteristik. Bahkan Pendidikan Agama Islam menyakini jika karakter, sifat, sikap, dan karakteristik kemudian sikap bersosialisasi lebih tinggi kadarnya sebagai penentu keberhasilan/kesuksesan peserta didik dibandingkan dengan kepintaran pikiran dan intelegensia (Sulaiman et al., 2018).

Betapa penting Emotional Quotient (EQ) hadir dan tertanam dalam diri peserta didik. Terlebih hakikat manusia sebagai makluk sosial yang tidak dapat menjalani kehidupan seorang diri tanpa adanya kehadiran orang lain disekitar dan sekelilingnya. Sehingga pendidikan sejatinya diawali pada lingkungan keluarga. Setiap orang tua di alam semesta pasti menginginkan dan mengimpikan anaknya menjadi insan yang berhasil, sukses, dan berprestasi. Seluruh orang tua tentunya menginginkan agar anaknya memiliki sensitivitas yang baik dalam merespon keberadaan dan kehadiran manusia lain disekitarnya. Terlebih dalam keluarga Islam, pasti memiliki harapan agar anak yang lahir dari keluarganya dapat menjadi individu yang terampil, pintar, memiliki kesehatan yang baik, memiliki kekuatan fisik yang baik, dan paling penting sekaligus terpenting dari seluruhnya yakni haruslah beriman.

Dalam keluarga Islam memiliki iman pastinya memiliki iman yang sesuai dengan ajaran Islam. Agar dapat sampai pada titik sasaran tersebut, keluarga dalam hal ini peran Ayah dan Ibu (Orang tua) sangat penting sebagai guru yang mendidik paling awal atau pertama dan terutama. Ayah dan Ibu (Orang tua) harus menyadari peran pentingnya tersebut. Sebelum anak menjadi peserta didik di institusi pendidikan seperti sekolah, Ayah dan Ibu lah yang pertama sekali mengajarkan dan melatih hal-hal baik kepada anak yang merupakan buah hatinya. Itulah pendidikan pertama kali yang diterima oleh anak (Aziz, 2017). Pendidikan dari orang tua kepada 
buah hatinya kurang memadai jika hanya menyerahkan $100 \%$ kepada institusi pendidikan. Harus disadari oleh orang tua, bahwa diri merekalah sesungguhnya pengajar paling baik bagi para buah hatinya. Orang tua yang baik, pastinya tidak sebatas mengajarkan pengetahuan kepintaran kepada buah hatinya, apakah dalam bentuk pembelajaran maupun jawaban atas poin-poin yang ditanyakan anaknya. Peranan orang tua diatas hal tersebut yakni harus dapat hadir sebagai panutan bagi buah hatinya. Hadirnya orang tua sebagai panutan bagi buah hatinya sangat penting. Anak biasanya akan meniru dan mencontoh apa yang dilakukan oleh orang tuanya (Izzah, 2018). Oleh sebab itu, orang tua wajib untuk hidup teratur dan baik sesuai dengan ajaran agama Islam. Sehingga anak juga akan melihat dan melakukan yang baik seperti yang dilakukan orang tuanya. Ketika anak melihat orang tuanya berkata kasar, mereka akan mencontohnya. Ketika ayah dan ibu suka bertengkar, maka anaknya akan memiliki karakter dan sifat demikian pula. Ketika Ayah dan Ibu bercerai, anak akan terkena imbas dari keretakan hubungan tersebut (Jaapar \& Azahari, 2011).

Anak sangat membutuhkan perhatian serta pengawasan yang konsisten serta berkelanjutan dari keluarga dalam hal ini orang tua. Bentuk perhatian serta pengawasan belajar meliputi memperhatikan buku-buku, catatan, dan kebersihan tas sekolah. Tak hanya itu, perhatian terkait perilaku, sikap, serta pembawaan anak juga wajib dilakukan. Dengan adanya perhatian dan pengawasan yang diberikan,maka dengan sendirinya rasa cinta anak kepada orang tuanya semakin besar. Sering kali dijumpai peserta didik tidak mempunyai perlengkapan belajar yang lengkap. Padahal lengkap tidaknya alat belajar menjadi faktor penghalang atau penghambat akivitas belajar anak.

Dalam istitusi pendidikan resmi atau formal ada yang dinamakan kurikulum. Kurikulum merupakan acuan untuk perjalanan pembelajaran pada periode tertentu. Setiap institusi pendidikan memiliki kurikulum beragam, sesuai dengan tujuan dan sasaran yang ingin dicapai oleh institusi pendidikan tersebut (Ramen Antonov Purba \& Verawardina, 2021). Keluarga tentu harus pula memiliki kurikulum pendidikan versi keluarga. Dibangun dan disusun oleh Ayah dan Ibu. Penjabarannya juga menjadi ranah Ayah dan Ibu jika diinginkan dapat pula melibatkan anggota keluarga yang lain. Komposisi kurikulum di tengah keluarga dapat difokuskan kepada penguatan akal pikiran dan penguatan unsur kerohanian anak (PAI, 1997). Selain itu terkait kreativitas dan jasmani dapat pula diikutsertakan. Mengacu kepada pengajaran Islam dapat pula dikolaborasikan dengan unsur pembentukan kepribadian. Disamping itu unsur rohani dan kajian kalbu korelasinya dengan pendidikan penguatan agama untuk anak harus dimasukkan. Haruslah diyakini jika pendidikan agama sangat berpengaruh tinggi sebagai pembentuk sudut pandang seorang anak dalam melihat dan menilai sesuatu. Sesuai dengan ajaran agama Islam terdapat dua fungsi pengaruh ketika pendidikan agama diterapkan secara konsisten di tengah keluarga, antara lain tertanamanya norma-norma perihal cara memandang kehidupan (Maulida, 2017). Hal ini akan menjadi warna dalam tumbuh kembang pikiran dan jasmani. Kemudian investasi tindakan dan perilaku. Hal ini akan menjadi fondasi dasar bagi anak ketika menjalani kehidupan diluar lingkungan rumah atau keluarga. Seperti memberikan hormat dan penghargaan terhadap orang lain, guru, maupun alam dan segala isinya. Demikian pula ketika menimba pengetahuan dan mengimplementasikan pengetahuan yang dimiliki secara nyata dan langsung (Alimah, 2019).

Oleh sebab itu, keluarga dalam hal ini orang yang tergabung dalam ikatannya haruslah mencerminkan nilai-nilai pengajaran agama Islam dalam kehidupan berkeluarga. Norma-norma 
yang diajarkan oleh agama Islam harus benar-benar diimplementasikan. Ayah dan Ibu maupun anggota keluarga yang lain dalam kategori usia dewasa harus dapat menjadi panutan dan contoh dalam semua aktivitas kehidupan yang dilakukan (Mujib, 2017). Dengan demikian akan dapat dilihat apakah anak sebagai buah hati dapat meneladani hal tersebut dan menjadikan apa yang didapatnya dikeluarga menjadi modal untuk hidup ditengah masyarakat yang majemuk dan heterogen. Seperti dalam penelitian ini yang dilakukan pada peserta didik MTS Negeri 2 Rantauprapat. Akan dilihat apakah terdapat pengaruh Intensitas Pendidikan Agama Islam di Lingkungan Keluarga Dengan EQ peserta didik yang menjalani pendidikan di MTS Negeri 2 Rantauprapat. Harapannya hasil dari penelitian dapat menjadi masukan sebagai bahan evaluasi untuk pengembangan dunia pendidikan khususnya di institusi Pendidikan Agama Islam, maupun pengajaran agama Islam di lingkungan keluarga.

Penelitian ini penting untuk dilakukan karena pada zaman sekarang, perkembangan teknologi yang begitu pesat mengakibatkan terkikisnya kecerdasan emosional peserta didik. Diakibatkan banyaknya media yang menyajikan dan memberikan informasi terkait ragam hal yang tidak terbendung. Penelitian ini juga penting untuk dilakukan karena kecerdasan emosional merupakan fondasi peserta didik dalam melakukan interaksi sosial. Dengan demikian, dapat diketahui secara jelas bagaimana pengaruh atau efek dan pentingnya Pendidikan Agama kepada kecerdasan emosional peserta didik.

\section{B. METODE PENELITIAN}

Penelitian menggunakan metode survei. Penelitian dengan metode survei merupakan penelitian dengan mengumpulkan sampel melalui sebuah populasi dengan mempergunakan daftar pertanyaan (Suliyanto \& MM, 2017). Kemudian menggunakan analisa regresi dalam melakukan pengukuran pengaruh berubahnya variable yang ada. Adapun pengukuran yang dilakukan dalam penelitian yakni pengaruh intensitas PAI di lingkungan keluarga terhadap Emotional Quotient (EQ) peserta didik di MTs Negeri 2 Rantauprapat.

Adapun jumlah sampel dalam penelitian ini sebanyak 140 orang peserta didik. Peserta didik dari kelas Tujuh dan Delapan MTs Negeri 2 Rantauprapat. Sesuai dengan pengamatan yang dilakukan pada objek penelitian yakni MTs Negeri 2 Rantauprapat, banyaknya kelas Rujuh dan Delapan sebanyak Enam kelas. Sesuai dengan pola pengumpulan sampel, adapun yang dijadikan sampel yakni Empat Puluh siswa dengan perhitungan 30 persen $\times 140$ peserta didik $=$ 42 mendapatkan pembulatan menjadi 40. Jadi sampel sebanyak 40 dari 140 peserta didik.

Adapun variabel dalam penelitian yakni intensitas PAI di lingkungan keluarga sebagai X. Kemudian yang menjadi indikator : peningkatan kapasitas daya sensitivitas, penanaman ilmu keagamaan, menumbuhkan stimulus, pendidikan aqi'dah, pendidikan syariah, dan pendidikan etika serta tingkah laku. Sedangkan Emotional Quotient (EQ) sebagai Y. Adapun indikator yaitu: Kesanggupan mengendalikan sifat emosional, Kesanggupan memanajemen sifat emosional, Kesanggupan menstimulus, berempati, serta keluwesan bergabung dalam kegiatan sosial. Yang menjadi model menganalisa data yakni dengan statistik. Dimana data yang ada akan disederhanakan sehingga gampang dipelajari serta diterjemahkan. Model penganalisaan data dengan : pengelompokan sesuai variabel kemudian tipe responden. Melakukan tabulasi sesuai variabel. Menampilkan data yang ada per variabel. Menghitung guna melakukan uji hipotesa. 


\section{HASIL DAN PEMBAHASAN}

Penelitian dilakukan dengan membagikan daftar pertanyaan dalam bentuk angket ke Empat Puluh peserta didik. Tujuannya guna memperoleh nilai berdasarkan uji lapangan terkait korelasi intensitas PAI di Lingkungan Keluarga dengan Emotional Quotient (EQ) peserta didik MTs Negeri 2 Rantauprapat. Banyaknya isian pada angket sejumlah Tujuh puluh isian. Tiga puluh lima bagian terkait intensitas PAI di Lingkungan Keluarga serta Tiga puluh lima lagi terkait Emotional Quotient (EQ) peserta didik MTs Negeri 2 Rantauprapat. Didapatkan nilai dimana Lima puluh empat isian yang Sesuai serta Terbukti sebanyak Dua puluh delapan isian terkait intensitas PAI di Lingkungan Keluarga kemudian Dua puluh enam isian tentang Emotional Quotient (EQ) peserta didik MTs Negeri 2 Rantauprapat. Berdasarkan nilai yang dihasilkan tersebut peneliti memilah X Dua puluh lima isian pertanyaan serta Y Dua puluh lima isian pertanyaan dengan hasil Sesuai. Dimana daftar isian dibagian ke Empat puluh peserta didik.

Pelajaran Pendidikan Agama Islam (PAI) mencakup akidah akhlak, alquran hadis, sejarah kebudayaan Islam, dan fikih. Tujuan tercapai ketika anak mampu menerapkan, mengaplikasikan, mengamalkan, dan mendemonstrasikan materi yang sudah dipelajari dalam kehidupan sehari-hari. Selain itu membawa perubahan ke arah yang lebih positif pada anak terlihat dari sikapnya. Mulai dari sopan santun, menghormati orang lain, bersikap rendah hati, hidup sederhana, saling tolong menolong, saling mengasihi sesama manusia dan lain sebagainya. Secara perlahan sikap-sikap terpuji tersebut akan tertanam dalam diri anak. Dengan demikian tercipta hasil belajar pendidikan agama Islam sesuai tujuan yang diharapkan (Firdaus, 2017).

\section{Intensitas PAI di Lingkungan Keluarga peserta didik (X)}

Pengembangan peningkatan keimanan dan ketakwaan peserta didik kepada Allah SWT sejatinya sedari dini ditanamkan dalam lingkungan keluarga. Penting sebagai penanaman nilai dan landasan hidup untuk mendapatkan kebahagiaan hidup di dunia dan akhirat. Juga penting untuk penyesuaian mental khususnya untuk menyelaraskan diri dengan lingkungan. Perbaikan dalam hal memperbaiki kesalahan, kekurangan serta kelemahan peserta didik mengenai keyakinan, pemahaman, dan pengamalannya dalam kehidupan sehari-hari juga diperlukan. Pencegahan dalam hal mencegah hal-hal negatif dari lingkungan maupun budaya lain yang dapat membahayakan dirinya serta mengganggu perkembangannya juga merupakan keharusan yang wajib. Pengawasan keluarga khususnya orang tua terhadap keberhasilan anaknya antara lain ditunjukkan dalam bentuk perhatian terhadap kegiatan keagamaan dan menekankan arti penting nilai-nilai keagamaan dalam pencapaian prestasi oleh sang anak, tapi disamping itu orang tua perlu menghadirkan pribadi sukses yang dapat dijadikan teladan bagi anak (Faridh, 2018).

Berdasarkan persebaran terhadap $X$ nilai paling tinggi diraih dengan antara 114-119 yakni sejumlah 14 adapun nilai sebesar 35\%. Selanjutnya yang urut dua yakni antara 108-113 sejumlah 10 adapun nilai sebesar 25\%. Berikutnya paling tinggi urut tiga yakni di antara 96-101 sejumlah 8 adapun nilai sebesar 20\%, kemudian antara 102-107 sebanyak 3 adapun nilai sebesar 7,5\% serta antara 120-125 sejumlah 3 adapun nilai sebesar 7,5\%. Kemudian paling akhir di antara 90-95 yakni sejumlah 2 adapun nilai sebesar 5\%. Nilai yang dihasilkan dapat digambarkan dalam bentuk grafik pada gambar 1 dibawah : 


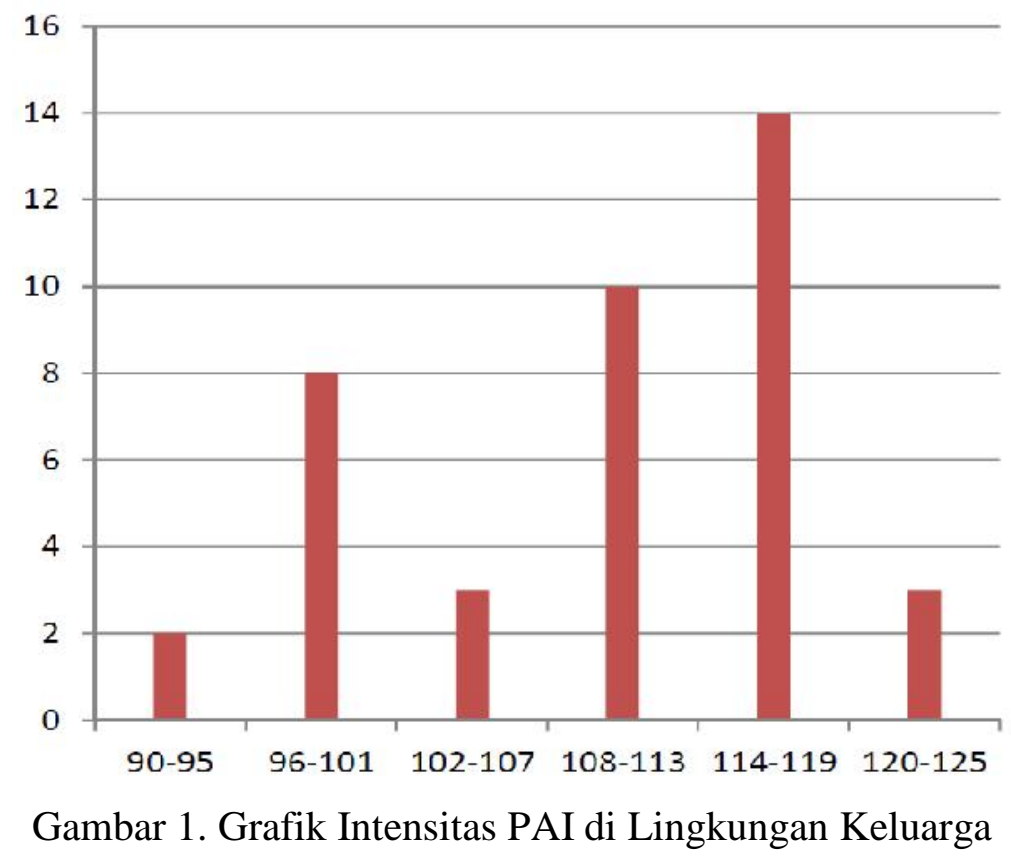

\section{Emotional Quotient (EQ) peserta didik}

Belajar merupakan sebuah perubahan dengan konteks yang secara relatif menetap yang terjadi dalam segala macam dan keseluruhan tingkah laku suatu sebagai hasil pengalaman. Belajar proses dimana tingkah laku ditimbulkan atau diubah melalui latihan atau pengalaman. Belajar aktivitas yang dilakukan secara sadar untuk mendapatkan sejumlah kesan dari bahan yang telah terjadi perubahan dalam diri individu. Bila tidak terjadi perubahan dalam diri individu, maka belajar dikatakan tidak berhasil. Seorang anak pasti akan berhasil dalam pembelajaran apabila orang tuanya senantiasa memenuhi perhatiannya dengan memberikan pengawasan dan mengontrol anak-anaknya ketika di rumah. Mengawasi dengan siapa saja anak bersosialisasi. Jika anak bergaul di lingkungan yang anak-anak yang rajin belajar, tentunya anak akan ikut rajin belajar. Begitupun sebaliknya. Anak akan malas belajar jika orang tua lalai tidak memberikan pengawasan serta pengontrolan jika anaknya bergaul di lingkungan tempat yang membuat anak malas untuk belajar. Pendidikan Agama Islam ialah kemampuan dan perubahan tingkah laku yang diperoleh siswa setelah mengikuti pembelajaran pendidikan agama Islam baik dari ranah kognitif, afektif maupun psikomotirik sehingga senantiasa berpedoman pada Alquran dan hadis dalam berkehidupan sehari-hari. Perhatian adalah pemusatan tenanga atau kekuatan jiwa tertuju pada suatu obyek. Perhatian merupakan konsentrasi atau aktivitas jiwa kita terhadap pengamatan, pengertian dengan mengesampingkan yang lain. Perhatian adalah pemusatan tenaga psikis tertuju kepada suatu objek (Rahimi, 2020).

Berdasarkan sebaran jumlah Y, diperoleh nilai paling tinggi didapatkan antara 110-113 yakni sejumlah 12 jumlah besaran 30\%. Kemudian antara 90-93 sejumlah 9 jumlah 22,5\% kemudian antara106-109 sejumlah 9 sejumlah 22,5\%. Berikutnya nilai paling tinggi urutan empat yakni di antara 98-101 sejumlah 5 besaran 12,5\%. Serta nilai paling tinggi nomor urut lima dengan antara 102-105 sejumlah 3 besaran 7,5\%, Kemudian paling akhir di antara 94-97 yakni sejumlah 2 besaran 5\%. Nilai yang dihasilkan dapat digambarkan dalam bentuk grafik pada gambar 2 dibawah: 


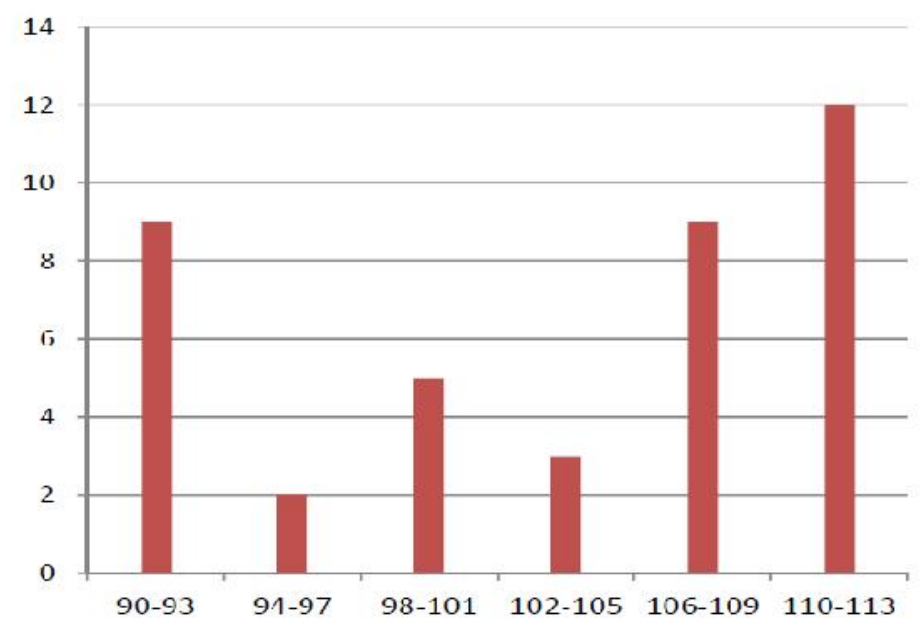

Gambar 2. Emotional Quotient (EQ) peserta didik

Dukungan ataupun motivasi dan dukungan semangat dari keluarga dalam hal ini orang tua sangat memberikan dan mempengaruhi kondisi kecerdasan emosional anaknya. Ketika anak terkendala dengan masalah terutama pembelajaran. Namun keluarga dalam hal ini orang tua tidak memperlihatkan bentuk perhatian serta kepeduliannya terhadap permasalahan yang sedang dialami oleh sang anak. Pastinya menjadikan serta membuat anak semakin putus asa. Lain halnya ketika anak sedang mengalami masalah seperti mendapatkan nilai yang tidak memuaskan. Kemudian orang tua tetap memberikan bentuk perhatian dengan menghibur atau memberi dorongan agar lebih giat belajar. Selain itu selalu memberikan motivasi agar anak menjadi tertantang serta tidak mudah putus asa. Dengan begitu, anak merasa orang tua sangat peduli akan pendidikan dan kehidupannya. Hal ini dapat memicu anak agar tidak pantang menyerah terhadap segala sesuatu yang dihadapi. Sebab berkat bantuan dari orang tua, ia dapat menyelesaikan berbagai kesulitan. Karenanya PAI ditengah keluarga sangat penting untuk mendukung anak berpikir bijaksana ketika mengalami permasalahan. Tidak hanya terkait permasalahan pembelajaran, tetapi juga terkait dengan permasalahan lain, misalnya permasalahan interaksi sosial yang berhubungan dengan kecerdasan emosionalnya.

Berdasarkan tahapan-tahapan yang dilakukan, diambil kesimpulan terdapat relasi intensitas PAI di Lingkungan Keluarga dengan Emotional Quotient (EQ) peserta didik MTs Negeri 2 Rantauprapat. Terlihat pada hasil koefisiensi kaitan didapatkan jika $r_{x y}=0,427>\mathrm{rt}$ $(0,05)=0,312$ begitupula $r_{x y}=0,427>\mathrm{rt}(0,01)=0,403$ dengan artian Relevan sehingga dugaan dengan pernyataan bahwa terdapat korelasi yang Relevan antara intensitas PAI di Lingkungan Keluarga dengan Emotional Quotient (EQ) peserta didik MTs Negeri 2 Rantauprapat bisa diterima. Seperti yang ditampilkan pada tabel 1 berikut :

Tabel 1. Ringkasan Korelasi

\begin{tabular}{lccccc}
\hline \multirow{2}{*}{ Uji Hipotesis } & \multirow{2}{*}{$\mathbf{r}$ hitung } & \multicolumn{2}{c}{ Taraf Signifikan } & Keterangan & Hipotesis \\
\cline { 3 - 6 } & & $\mathbf{5 \%}$ & $\mathbf{1 \%}$ & & \\
\hline $\mathrm{r}_{\mathrm{xy}}$ & 0,427 & 0,312 & 0,403 & Signifikan & Diterima \\
\hline
\end{tabular}


Pada test $F_{\text {reg }}$ didapatkan, jika valuenya sejumlah 8,495, dan result yang didapatkan dikonsultasikan dengan tabel $\mathrm{F}_{\mathrm{t}}$ taraf signifikansi $5 \%=4,10$ dan taraf signifikansi $1 \%=7,35$. Sehingga, $F_{\text {reg }}=8,495>\mathrm{F}_{\mathrm{t}}(0,05)=4,10$ begitupula $\mathrm{F}_{\text {reg }}=8,495>\mathrm{F}_{\mathrm{t}}(0,01)=7,35$ berarti signifikan. Seperti yang ditampilkan pada tabel 2 berikut :

Tabel 2. Ringkasan Korelasi Uji

\begin{tabular}{lcrrrr}
\hline \multirow{2}{*}{ Uji Hipotesis } & \multirow{2}{*}{ F hitung } & \multicolumn{2}{c}{ Taraf Signifikan } & Keterangan & Hipotesis \\
\cline { 3 - 6 } & & $\mathbf{5 \%}$ & $\mathbf{1 \%}$ & & \\
\hline $\mathrm{F}_{\mathrm{reg}}$ & 8,495 & 4,10 & 7,35 & Signifikan & Diterima \\
\hline
\end{tabular}

Berdasarkan urutan paparan yang telah dilakukan bisa diambil kesimpulan, bahwa terdapat hubungan positif antara intensitas PAI dalam keluarga dengan Emotional Quotient (EQ) peserta didik MTs Negeri 2 Rantauprapat. Pendidikan Agama Islam yang rutin dilakukan dalam keluarga secara langsung memberikan dampak yang positif terhadap perkembangan Emotional Quotient (EQ) peserta didik. Hal ini sejalan dengan penelitian (Iswahyudi et al., 2021; Masduqi, 2021) yang mengatakan bahwa, dilakukannya Pendidikan Agama Islam dalam keluarga merupakan salah satu bentuk dari perhatian keluarga kepada peserta didik. Situasi ini akan melatih pemikiran peserta didik bahwa keluarga benar-benar peduli dengan kehidupan mereka, yang berdampak positif terhadap kecerdasan emosionalnya.

Tidak ada orang tua yang menginginkan kecerdasan emosional anaknya terganggu. Karena itu menjadi kewajiban bagi setiap orang tua sedari dini untuk menanamkan nilai-nilai keagamaan kepada anaknya. Diawali dari dalam keluarga yang kemudian akan mempengaruhi kecerdasan emosional anak ketika berinteraksi di lingkungan diluar keluarga. Kondisi demikian yang didapati dari penelian yang dilakukan terhadap peserta didik di MTs Negeri 2 Rantauprapat. Seperti penelitian (Anjarini, 2018) yang mengatakan bahwa, keluarga merupakan sekolah paling utama dalam menumbuhkan nilai-nilai kecerdasan emosional melalui pendekatan keagamaan kepada anak. Sehingga ketika si anak berinteraksi secara sosial dilingkungan di luar rumah tinggalnya, si anak akan tertap bertingkah laku baik, karena telah ditanamkan fondasi keagamaan yang membawa pengaruh positif terhadap kecerdasan emosionalnya.

Keluarga dalam hal ini Orang tua sangat penting untuk memberikan perhatian secara intensif kepada anaknya secara terus-menerus. Sehingga anak akan senantiasa merasa keluarga dalam hal ini orang tuanya tidak bersikap acuh. Perhatian ini sangat penting, karena banyak anak-anak yang terganggu kecerdasan emosionalnya karena kurangnya perhatian dari keluarga dalam hal ini orang tuanya. Seperti penelitian (Agustina et al., 2020; Wahyuni \& Bahtiar, 2016) yang mengatakan bahwa perhatian orang tua merupakan salah satu dasar dari keterbentukan pola pikir anak. Karenanya ketika ada keluarga yang secara berkesinambungan dan berkelanjutan menanamkan pendidikan keagamaan kepada anaknya, maka anak tersebut pasti akan terbina dan terbentuk pola pikirnya berlandaskan nilai-nilai agama yang ditanamkan kepadanya. Seperti hasil penelitian ini, di mana secara jelas dan nyata terdapat korelasi ataupun hubungan antara PAI di keluarga dengan kecerdasan emosional anak.

Pendidikan Agama Islam bertujuan membentuk akhlak mulia juga menciptakan manusia yang bertakwa, memperoleh kebahagiaan dunia dan akhirat serta meningkatkan keimanan terhadap Tuhan Yang Maha Esa. Karenanya sangat penting untuk menanamkan fondasi 
pendidikan ini dalam keluarga, khususnya kepada anak yang duduk di bangku sekolah. Sehingga seperti hasil penelitian, intensitas PAI dalam keluarga memberikan peningkatan kepada peserta didik khususny dalam kecerdasan emosionalnya. Seperti penelitian (Muslimin, 2016) yang mengatakan bahwa, salah satu faktor penting yang merubah cara pandang dan pola pikir peserta didik yakni seringnya peserta didik tersebut mendapatkan pembelajaran terkait agama tidak hanya di sekolah sebagai lembaga pendidikan resmi, tetapi juga di keluarga.

\section{KESIMPULAN}

Terdapat hubungan positif antara intensitas PAI di Lingkungan keluarga dengan Emotional Quotient (EQ) peserta didik MTs Negeri 2 Rantauprapat. Terlihat dari nilai koefisiensi korelasi diketahui bahwa $r_{\mathrm{xy}}=0,427>\mathrm{r}_{\mathrm{t}}(0,05)=0,312$ kemudian tingkat signifikan $r_{\mathrm{xy}}=0,427>\mathrm{r}_{\mathrm{t}}(0,01)=0,403$ berarti signifikan.

Terdapat hubungan positif antara intensitas PAI di Lingkungan keluarga dengan

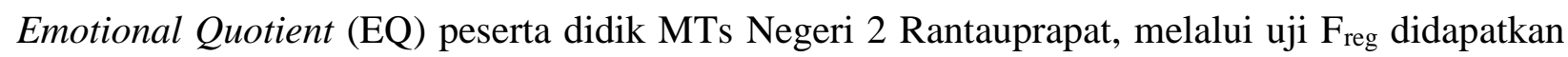
nilai 8,495, berikutnya hasil dikonsultasikan dengan tabel $\mathrm{F}_{\mathrm{t}}(0,05)=4,10$ dan $\mathrm{F}_{\mathrm{t}}(0,01)=7,35$. Sehingga $\mathrm{F}_{\text {reg }}=8,495>\mathrm{F}_{\mathrm{t}}(0,05)=4,10$ kemudian $\mathrm{F}_{\mathrm{t}}(0,01)=7,35$ sehingga hipotesa yang menyatakan terdapat hubungan positif antara intensitas PAI di Lingkungan keluarga dengan Emotional Quotient (EQ) peserta didik MTs Negeri 2 Rantauprapat dapat diterima.

\section{DAFTAR PUSTAKA}

Agustina, W., Hamengkubuwono, H., \& Syahindra, W. (2020). Model pembelajaran Pendidikan Agama Islam di Sekolah Umum. AT-TA'DIB: Jurnal Ilmiah Prodi Pendidikan Agama Islam, 112-126.https://doi.org/10.47498/tadib.v12i02.365

Alimah, L. N. (2019). Pengaruh lingkungan keluarga dan lingkungan Sekolah terhadap sikap sosial Siswa pada Mata Pelajaran PAI Kelas VII di SMP Negeri 1 Mlarak Ponorogo Tahun Ajaran 2018/2019. IAIN Ponorogo.

Anjarini, A. D. A. (2018). Analisis pengaruh Emotional Quotient, Intelligence Quotient dan Spiritual Quotient terhadap kepuasan kerja dan kinerja Guru di Sekolah Luar Biasa Negeri Batang. BBM (Buletin Bisnis \& Manajemen), 3(1). http://dx.doi.org/10.47686/bbm.v3i1.35

Aziz, S. (2017). Pendidikan spiritual berbasis Sufistik bagi Anak Usia Dini dalam keluarga. Dialogia: Jurnal Studi Islam Dan Sosial, 15(1), 131-149. https://doi.org/10.21154/dialogia.v15i1.1188

Batubara, I. F. (2021). Konsep Penciptaan Alam Menurut Islam dan Kristen. Universitas Islam Negeri Sumatera Utara.

Boiliu, F. M. (2018). Model pendidikan yang cocok dalam Masyarakat Majemuk di Indonesia: Pendidikan Agama yang Inklusif dan Pendidikan Agama yang Multikultural.

Faridh, T. A. (2018). Emotional and Spiritual Intelligence (ESQ) of Children in Islamic Education in the Family Environment. Didaktika Religia, 6(1), 51-66.

Firdaus, Z. (2017). Pengaruh Pendidikan Agama Islam dan Budaya Religius Sekolah terhadap Kecerdasan Emosional dan Spiritual Siswa. Al-Hikmah: Jurnal Kependidikan Dan Syariah, 5(2), 46-55. https://jurnal.staiba.ac.id/index.php/Al-Hikmah/article/view/44 
Hanafie Das, S. W., Halik, A., \& Besse, A. (2020). Strategi Pembelajaran Pendidikan Agama Islam Berbasis Quipper School di Sekolah. Uwais Inspirasi Indonesia.

Herwati, H. (2016). Emotional spiritual qoutient (ESQ) dan relevasinya terhadap pendidikan agama Islam: Telaah pemikiran Ary Ginanjar Agustian dan pemikiran Muhammad Ustman An-Najati. Universitas Islam Negeri Maulana Malik Ibrahim.

Iswahyudi, P., Sulung, S. D., Haricahyo, D., \& Martono, H. E. (2021). Pengaruh Intelegence Quotient, Emotional Quotient dan Spiritual Quotient (SQ) terhadap prestasi belajar Mata Kuliah Pendidikan Pancasila pada Taruna Diploma III Penerbang Sayap Tetap Angkatan I di Akademi Penerbang Indonesia Banyuwangi. SKYHAWK: Jurnal Aviasi Indonesia, 1(1), 7-13. http://ejournal.icpa-banyuwangi.ac.id/index.php/skyhawk/article/view/3

Izzah, I. (2018). Peran Pendidikan Agama Islam dalam Membentuk Masyarakat Madani. PEDAGOGIK: Jurnal Pendidikan, 5(1), 50-68. https://doi.org/10.33650/pjp.v5i1.219

Jaapar, N. Z. H., \& Azahari, R. (2011). Model Keluarga Bahagia Menurut Islam. Jurnal Fiqh, 8, 25-44. https://ejournal.um.edu.my/index.php/fiqh/article/download/4332/2608/11199

Masduqi, A. (2021). Pengelolaan program unggulan Pendidikan Agama Islam di Sekolah Menengah Kejuruan berbasis Pesantren. AT-TA'DIB: Jurnal IImiah Prodi Pendidikan Agama Islam, 1-14. https://doi.org/10.47498/tadib.v13i01.501

Maulida, A. (2017). Kurikulum Pendidikan Akhlak Keluarga dan Masyarakat dalam Hadits Nabawi. Edukasi Islami: Jurnal Pendidikan Islam, 3(06). http://dx.doi.org/10.30868/ei.v3i06.59

Mujib, A. (2017). Teori kepribadian perspektif psikologi Islam. Rajawali Pers.

Muslimin, N. (2016). Pendidikan Agama Islam berbasis IQ, EQ, SQ dan CQ. KABILAH: Journal of Social Community, 1(2), 255-273. http://ejournal.kopertais4.or.id/madura/index.php/kabilah/article/view/2863

PAI, A. (1997). Pendidikan Agama Islam. Jurnal, Diakses Pada, 18(10), 2018.

Purba, Ramen A, Mawati, A. T., Ardiana, D. P. Y., Pramusita, S. M., Bermuli, J. E., Purba, S. R. F., Sinaga, K., Mardiana, N., Rofiki, I., \& Recard, M. (2021). Media dan Teknologi Pembelajaran. Yayasan Kita Menulis.

Purba, Ramen A, Rofiki, I., Purba, S., Purba, P. B., Bachtiar, E., Iskandar, A., Febrianty, F., Yanti, Y., Simarmata, J., \& Chamidah, D. (2020). Pengantar Media Pembelajaran. Yayasan Kita Menulis.

Purba, Ramen Antonov. (2018). Memprediksi prestasi mahasiswa Politeknik Unggul LP3M dengan menggunakan Jaringan Saraf Tiruan dan Fuzzy. SEMNASTEKNOMEDIA ONLINE, 6(1), 2-12. https://ojs.amikom.ac.id/index.php/semnasteknomedia/article/view/1998

Purba, Ramen Antonov. (2021). Efektivitas aplikasi UAS Online dalam menjaga mutu prkuliahan di Masa Pendemi COVID-19. Jurnal Pendidikan Teknologi Dan Kejuruan, 18(2), 185-194. http://dx.doi.org/10.23887/jptk-undiksha.v18i2.34101

Purba, Ramen Antonov, \& Verawardina, U. (2021). Deteksi Mahasiswa yang dapat Menyusun Tugas Akhir dengan Metode Visekriterijumsko Kompromisno Rangiranje (VIKOR). Techno. Com, 20(2), 210-220. https://doi.org/10.33633/tc.v20i2.4360

Rahimi, R. (2020). Konsep Pendidikan Karakter Ditinjau dari Perspektif Psikologi Islam. ATTA'DIB: Jurnal IImiah Prodi Pendidikan Agama Islam, 174-181. https://doi.org/10.47498/tadib.v12i02.405 
Rosyida, N. N. (2020). Korelasi Antara Hasil Belajar Mata Pelajaran Pendidikan Agama Islam (PAI) dengan Emotional Quotient (EQ) Peserta Didik di SMP Negeri 2 Prambon Nganjuk. UIN Sunan Ampel Surabaya.

Saputra, G. (2019). Penciptaan Alam Semesta Menurut Harun Yahya: Studi Kritis Perspektif Kosmologi Modern, Kosmologi Islam, dan Teologi Natural. UIN Sunan Ampel Surabaya.

Sudarmanto, E., Purba, R. A., Nur, N. K., Revida, E., Hasibuan, A., Recard, M., Samsir, S., Simbolon, I., Chaerul, M., \& Tambunan, E. H. (2021). Pengembangan Budaya Akademik. Yayasan Kita Menulis.

Sulaiman, M., Al Hamdani, M. D., \& Aziz, A. (2018). Emotional Spiritual Quotient (ESQ) dalam Pembelajaran Pendidikan Agama Islam Kurikulum 2013. Jurnal Penelitian Pendidikan Islam,[SL], 6(1), 77-110. https://doi.org/10.36667/jppi.v6i1.156

Suliyanto, S. E., \& MM, S. (2017). Metode Penelitian Kuantitatif.

Syahrum, S., Usman, S., \& Yamin, N. (2019). Pengaruh Profesionalisme Guru dan Kecerdasan Emosional Terhadap Kinerja Guru Pendidikan Agama Islam di MTS Negeri 2 Bulukumba. Manajemen Pendidikan, 14(1), 38-44. DOI: 10.23917/jmp.v14i1.8514

Wahyuni, N., \& Bahtiar, A. R. (2016). Hubungan Emotional Quotient dengan Kemampuan Guru PAI dalam Menanamkan Nilai-nilai Moral Keagamaan. TARBAWI: Jurnal Pendidikan Agama Islam, 1(1), 77-84. https://doi.org/10.26618/jtw.v1i1.360 